\title{
Pengaruh Penerapan Model Pembelajaran Thinking Aloud Pair Problem Solving (TAPPS) terhadap Kemampuan Pemecahan Masalah Matematika
}

\author{
Widya Nusywari $^{1, \text { a) }}$, Sudi Prayitno ${ }^{2, \text { b) }}$, Junaidi ${ }^{3, \text { c) }}$, Nurul Hikmah ${ }^{4, d)}$ \\ ${ }^{1234}$ Universitas Mataram, Mataram, Nusa Tenggara Barat

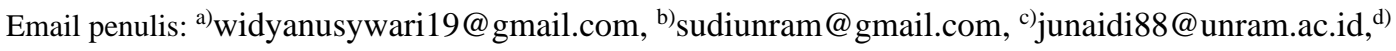 \\ uyununram@gmail.com
}

\begin{abstract}
This study aims to determine the effect of the Thinking Aloud Pair Problem Solving (TAPPS) learning model on the mathematical problem solving abilities of eighth grade students of SMP. This research is a quasiexperimental research with Non-Equivalent Control Group Design. The population in this study were all eighth grade students of SMP. In determining the sample, the saturated sample technique was used, where the samples in this study were class VIII-A as the control class and class VIII-B as the experimental class. The instrument used in this research is a test of mathematical problem solving ability on number pattern material. Quantitative data analysis was performed using a gain t-test. The results of data analysis obtained thitung $=2.14$ and ttable $=$ 2.064 so that thitung > ttable then $\mathrm{HO}$ is rejected which indicates that there are differences in students' mathematical problem solving abilities between classes that receive TAPPS learning and direct learning. This shows that learning with the TAPPS model has an effect on the mathematical problem solving abilities of eighth grade students of SMP. The influence of the application of the Thinking Aloud Pair Problem Solving (TAPPS) learning model on the mathematical problem solving ability of class VIII students at SMP on the number pattern material using the effect size formula (d) is 1.907 , which means that the effect given has a high category.
\end{abstract}

Keywords: learning model, thinking aloud pair problem solving (TAPPS), problem solving ability

\begin{abstract}
Abstrak
Penelitian ini bertujuan untuk mengetahui adanya pengaruh model pembelajaran Thinking Aloud Pair Problem Solving (TAPPS) terhadap kemampuan pemecahan masalah matematika peserta didik kelas VIII SMP. Penelitian ini merupakan penelitian kuasi eksperimen dengan desain penelitian Non-Equivalen Control Group Design. Populasi dalam penelitian ini adalah seluruh peserta didik kelas VIII SMP. Dalam menentukan sampel digunakan teknik sampling jenuh, dimana sampel pada penelitian ini adalah kelas VIII-A sebagai kelas kontrol dan kelas VIII-B sebagai kelas eksperimen. Instrumen yang digunakan dalam penelitian ini adalah tes kemampuan pemecahan masalah matematika pada materi pola bilangan. Analisis data kuantitatif dilakukan dengan menggunakan gain uji-t. Hasil analisis data didapatkan $t_{\text {hitung }}=2,14$ dan $t_{\text {tabel }}=2,064$ sehingga $t_{\text {hitung }}>t_{\text {tabel }}$ maka $H_{0}$ ditolak yang menunjukkan bahwa terdapat perbedaan kemampuan pemecahan masalah matematika peserta didik antara kelas yang memperoleh pembelajaran TAPPS dan pembelajaran langsung. Hal ini menunjukkan bahwa pembelajaran dengan model TAPPS berpengaruh terhadap kemampuan pemecahan masalah matematika peserta didik kelas VIII SMP. Besar pengaruh penerapan Model pembelajaran Thinking Aloud Pair Problem Solving (TAPPS) terhadap kemampuan pemecahan masalah matematika peserta didik kelas VIII di SMP pada materi pola bilangan dengan menggunakan rumus effect size (d) sebesar 1,907 yang artinya pengaruh yang diberikan memiliki kategori tinggi.
\end{abstract}

Kata kunci: model pembelajaran, thinking aloud pair problem solving (TAPPS), kemampuan pemecahan masalah

Copyright (c) 2022 Nusywari, Prayitno, Junaidi, Hikmah

$\triangle$ Corresponding author:

Email Address: widyanusywari19@gmail.com

Received 20 Januari 2022, Accepted 23 Februari 2022, Published 24 Februari 2022

https://doi.org/10.21009/jrpmj.v4i1.23023 


\section{PENDAHULUAN}

Pendidikan yang baik adalah pendidikan yang tidak hanya mempersiapkan para peserta didiknya untuk suatu profesi atau jabatan, tetapi untuk menyelesaikan masalah-masalah yang dihadapinya dalam kehidupan sehari-hari (Trianto, 2007).

Matematika berkenaan dengan ide-ide (gagasan-gagasan), struktur-struktur dan hubunganhubungan yang diatur secara logis sehingga matematika itu berkaitan dengan konsep-konsep abstrak (Turmuzi, 2017). Kemampuan pemecahan masalah merupakan bagian dari kurikulum matematika yang sangat penting karena dalam proses pembelajaran maupun penyelesaiannya, peserta didik dimungkinkan memperoleh pengalaman menggunakan pengetahuan dan keterampilan yang sudah dimiliki untuk diterapkan (Suherman, 2003). Kemampuan pemecahan masalah dapat juga diartikan sebagai kapasitas seorang peserta didik dalam usaha menyelesaikan suatu permasalahan dengan memanfaatkan segala pengetahuan yang dimiliki (Turmuzi, 2018).

Meskipun kemampuan pemecahan masalah merupakan suatu kemampuan penting yang harus dimiliki peserta didik, namun pada kenyataannya kemampuan pemecahan masalah peserta didik di Indonesia masih tergolong rendah khususnya di SMP-IT Darul Muhsin Nahdlatul Wathan kelas VIII. Hal ini dapat dilihat dari nilai UAS peserta didik semester ganjil pada mata pelajaran matematika tahun ajaran 2019/2020 masih banyak dibawah KKM. Untuk lebih jelasnya dapat dilihat pada tabel dibawah ini.

\begin{tabular}{ccc}
\hline No & Nilai UAS Kelas A & Nilai UAS Kelas B \\
\hline 1 & 20 & 30 \\
\hline 2 & 25 & 27,5 \\
\hline 3 & 35 & 35 \\
\hline 4 & 20 & 27,5 \\
\hline 5 & 27,5 & 30 \\
\hline 6 & 17,5 & 30 \\
\hline 7 & 75 & 37,5 \\
\hline 8 & 75 & 75 \\
\hline 9 & 35 & 32,5 \\
\hline 10 & 65 & 42,5 \\
\hline 11 & 25 & 75 \\
\hline 12 & 12,5 & 57,5 \\
\hline 13 & 20 & \\
\hline 14 & 12,5 & \\
\hline
\end{tabular}

Tabel 1. Nilai Ujian Akhir Sekolah Kelas VIII SMP-IT Darul Muhsin Nahdlatul Wathan.

Berdasarkan hasil observasi diketahui bahwa dimana pada saat pembelajaran guru lebih aktif, kurangnya interaksi antar peserta didik, pada saat peserta didik menjawab soal peserta didik lebih mengutamakan hasil akhir atau jawaban yang diperoleh daripada proses pengerjaan soal tersebut dan 
peserta didik masih kesulitan dalam menyelesaikan soal-soal yang berbentuk cerita. Salah satu strategi untuk mengatasi kesalahan-kesalahan yang dilakukan peserta didik dalam menyelesaikan soal cerita yaitu bisa dengan menerapkan strategi pemecahan masalah yang disusun oleh Polya.

Terkait rendahnya kemampuan matematika peserta didik sampai saat ini, sudah saatnya untuk membenahi proses pembelajaran matematika terutama mengenai model, pendekatan, atau metode pembelajaran yang digunakan dalam proses pembelajaran. Dalam memecahkan masalah matematika ada beberapa kegiatan atau tahapan yang dilakukan, yaitu memahami masalah, menyusun rencana penyelesaian, melaksanakan rencana, dan melihat (memeriksa) kembali solusi. Hal tersebut dilakukan dengan tujuan agar peserta didik menjadi lebih trampil dan cermat dalam menyelesaikan masalah matematika. Untuk membuat kemampuan pemecahan masalah matematika peserta didik lebih meningkatkan perlu dipilih model pembelajaran yang diharapkan mampu mengatasi permasalahan peserta didik dalam proses pembelajaran didalam kelas.

Menurut penelitian yang dilakukan oleh (Wulandari et al., 2013) dan (Setiawati et al., 2015) model pembelajaran Thinking Aloud Pair Problem Solving (TAPPS) dapat meningkat keterampilan kemampuan pemecahan masalah matematika. Sehingga model pembelajaran yang diharapkan mampu mengatasi masalah tersebut yaitu model Thinking Aloud Pair Problem Solving (TAPPS). Model pembelajaran TAPPS merupakan teknik pembelajaran dengan landasan metode pembelajaran kolaboratif ini diungkapkan oleh Lochhead dan Whimbey sebagai satu cara untuk mengembangkan keterampilan pemecahan masalah dengan cara menyatakan secara verbal, membaca dengan nyaring masalah yang harus dipecahkan. Dalam hal ini, peserta didik secara berpasang-pasangan untuk menyelesaikan permasalahan yang terdapat dalam kehidupan sehari-hari. Setiap kelompok terdiri dari dua orang peserta didik yang diberi peranan yang berbeda satu sama lain pada setiap masalah. Satu orang peserta didik menjadi pemecahan masalah atau problem solver (PS) dan satu orang peserta didik lagi menjadi pendengar atau listener (L). Setiap kelompok mempunyai tugas masing-masing yang akan mengikuti aturan tertentu (Khabibah \& Sari, 2017). Adapun langkah-langkah dari model pembelajaran TAPPS menurut Watson (Warsono \& Hariyanto. 2017) yaitu (1) menyampaikan materi, (2) membentuk kelompok, (3) membagikan masalah, (4) menyelesaikan masalah berpasangan, (5) mempresentasikan hasil kelompok.

\section{METODE}

Jenis penelitian yang digunakan adalah eksperimen. Desain penelitian yang digunakan adalah Pretest-Posttest Non-Equivalen Control Group Design. Penelitian ini dilaksanakan di SMP-IT Darul Muhsin Nahdlatul Wathan tahun ajaran 2020/2021. Populasi dan sampel dalam penelitian ini adalah seluruh peserta didik kelas VIII SMP-IT Darul Muhsin NW tahun ajaran 2020/2021 yang berjumlah 26 orang. Dengan menggunakan teknik sampling jenuh.

Pada penelitian ini, kelas VIII B sebagai kelas eksperimen yang menggunakan model pembelajaran Thinking Aloud Pair Problem Solving (TAPPS), sedangkan kelas VIII A sebagai kelas 
kontrol yang menggunakan model pembelajaran langsung. Penelitian ini diakukan sebanyak enam kali pertemuan, dimana enam kali pertemuan tersebut terdiri dari empat kali pertemuan untuk melakukan proses pembelajaran, satu kali digunakan untuk melakukan pretest, dan satu kali digunakan untuk melakukan posttest. Variabel bebas dalam penelitian ini adalah model pembelajaran Thinking Aloud Pair Problem Solving (TAPPS) dan variabel terikat dalam penelitian ini adalah kemampuan pemecahan masalah matematika peserta didik. Metode pengumpalan data yang digunakan adalah observasi dan tes. Instrumen dalam penelitian ini adalah soal tes (pretest dan posttest), lembar observasi yang terdiri dari lembar observasi aktivitas mengajar guru, serta lembar observasi aktivitas peserta didik. Bukti validitas menggunakan validitas isi dilakukan oleh seorang dosen pendidikan matematika Universitas Mataram.

Teknik analisis data yang digunakan dalam penelitian ini adalah uji prasyarat dan uji hipotesis, uji prasyarat yang digunakan adalah uji normalitas dengan mengggunakan uji Liliefors, dengan rumus (Sundayana, 2016) yaiitu.

Keterangan:

$$
L=|F(Z)-S(Z)|
$$

$L \quad$ : nilai Uji Liliefors hitung

Z : simpangan baku kurva standar

$F(Z) \quad$ : besar peluang untuk masing-masing nilai $\mathrm{Z}$

$S(Z) \quad$ : frekuensi komulatif dari masing-masing nilai $\mathrm{Z}$

Jika $L_{\text {hitung }} \leq L_{\text {tabel }}$ maka data berdistribusi normal, dan jika $L_{\text {hitung }}>L_{\text {tabel }}$ maka data tidak berdistribusi normal.

Dan uji homogenitas dengan menggunakan uji Fisher dengan rumus (Sugiyono, 2013) yaitu.

$$
F_{\text {hitung }}=\frac{\text { varian terbesar }}{\text { varian terkecil }}
$$

Kreteria uji: jika $F_{\text {hitung }} \leq F_{\text {tabel }}$, maka $H_{0}$ diterima (Varians homogen).

Sedangkan untuk uji hipotesis digunakan Gain uji-t. Rumus Gain uji-t menurut (Arikunto, 2013) yaitu:

$$
t_{\text {hitung }}=\frac{\left|M_{X}-M_{Y}\right|}{\sqrt{\left(\frac{\sum X^{2}+\sum Y^{2}}{N_{X}+N_{Y}-2}\right)\left(\frac{1}{N_{X}}+\frac{1}{N_{Y}}\right)}}
$$

Keterangan:

$\mathrm{M}_{\mathrm{X}} \quad=$ selisih nilai rata-rata pretest dan posttest kelas eksperimen

$\mathrm{M}_{\mathrm{Y}} \quad=$ selisih nilai rata-rata pretest dan posttest kelas kontrol

$\mathrm{N}_{\mathrm{X}} \quad$ = banyaknya peseta didik kelas eksperimen

$\mathrm{N}_{\mathrm{Y}} \quad$ = banyaknya peseta didik kelas kontrol 
$X \quad=$ deviasi nilai pretest dan posttest kelas eksperimen

$Y \quad=$ deviasi nilai pretest dan posttest kelas kontrol

Ingat bahwa: $\sum X^{2}$ dapat diperoleh dari $\sum x^{2}-\frac{\left(\sum x\right)^{2}}{N}$ dan

$$
\sum Y^{2} \text { dapat diperoleh dari } \sum y^{2}-\frac{\left(\sum y\right)^{2}}{N}
$$

Setelah didapatkan $t$ hitung, kemudian $t$ hitung dikonsultasikan dengan $t$ tabel pada taraf signifikansi $5 \%$. Jika $t_{\text {hitung }}>t_{\text {tabel }}$ maka $H_{0}$ ditolak atau $H_{1}$ diterima.

Hipotesis yang diuji adalah:

Selisih rata-rata kemampuan pemecahan masalah matematika kelas eksperimen yang menggunakan model Thinking Aloud Pair Problem Solving (TAPPS) lebih dari selisih rata-rata kemampuan pemecahan masalah matematika kelas kontrol yang menggunakan model pembelajaran langsung.

Untuk mengetahui seberapa besar pengaruh penerapan model pembelajaran Thinking Aloud Pair Problem Solving (TAPPS) terhadap kemampuan pemecahan masalah matematika peserta didik kelas VIII SMP-IT Darul Muhsin NW menggunakan perhitungan Effect Size. Rumus Effect Size menurut Warner (Wijayanti \& Taat, 2016) yaitu:

$$
d=\frac{\bar{X}_{2}-\bar{X}_{1}}{S}
$$

Keterangan:

$$
\begin{array}{ll}
d & =\text { Effect Size } \\
\bar{X}_{2} & =\text { Mean Pretest } \\
\bar{X}_{1} & =\text { Mean Posttest } \\
S & =\text { Standar Deviasi Posttest }
\end{array}
$$

Kriteria yang diusulkan oleh Cohen (Wijayanti \& Taat) tentang besar kecilnya ukuran Effect Size sebagai berikut.

\begin{tabular}{cc}
\hline Efeect Size & Keterangan \\
\hline$d \leq 0,2$ & Rendah \\
$0,2<d \leq 0,8$ & Sedang \\
$d>0,8$ & Tinggi \\
\hline
\end{tabular}

\begin{tabular}{|c|c|c|c|c|}
\hline No & \multicolumn{2}{|c|}{$\begin{array}{c}\text { Tahapan Pemecahan } \\
\text { Masalah }\end{array}$} & Deskripsi & Skor \\
\hline \multirow[t]{3}{*}{1} & \multirow{3}{*}{$\begin{array}{l}\text { Memahami } \\
\text { Masalah }\end{array}$} & \multirow[t]{3}{*}{ Diketahui } & Tidak menuliskan apa yang diketahui & 0 \\
\hline & & & Menuliskan diketahui tetapi salah & 1 \\
\hline & & & Menuliskan apa yang diketahui tetapi & 2 \\
\hline
\end{tabular}

Tabel 2. Kriteria Effect Size

\section{HASIL DAN PEMBAHASAN}

Sebelum menganalisis uji prasyarat dan uji hipotesis, terlebih dahulu mencari nilai yang diperoleh peserta didik saat melakukan tes dengan menggunakan pedoman penilaian yang telah dibuat pada Tabel 3. berikut. 


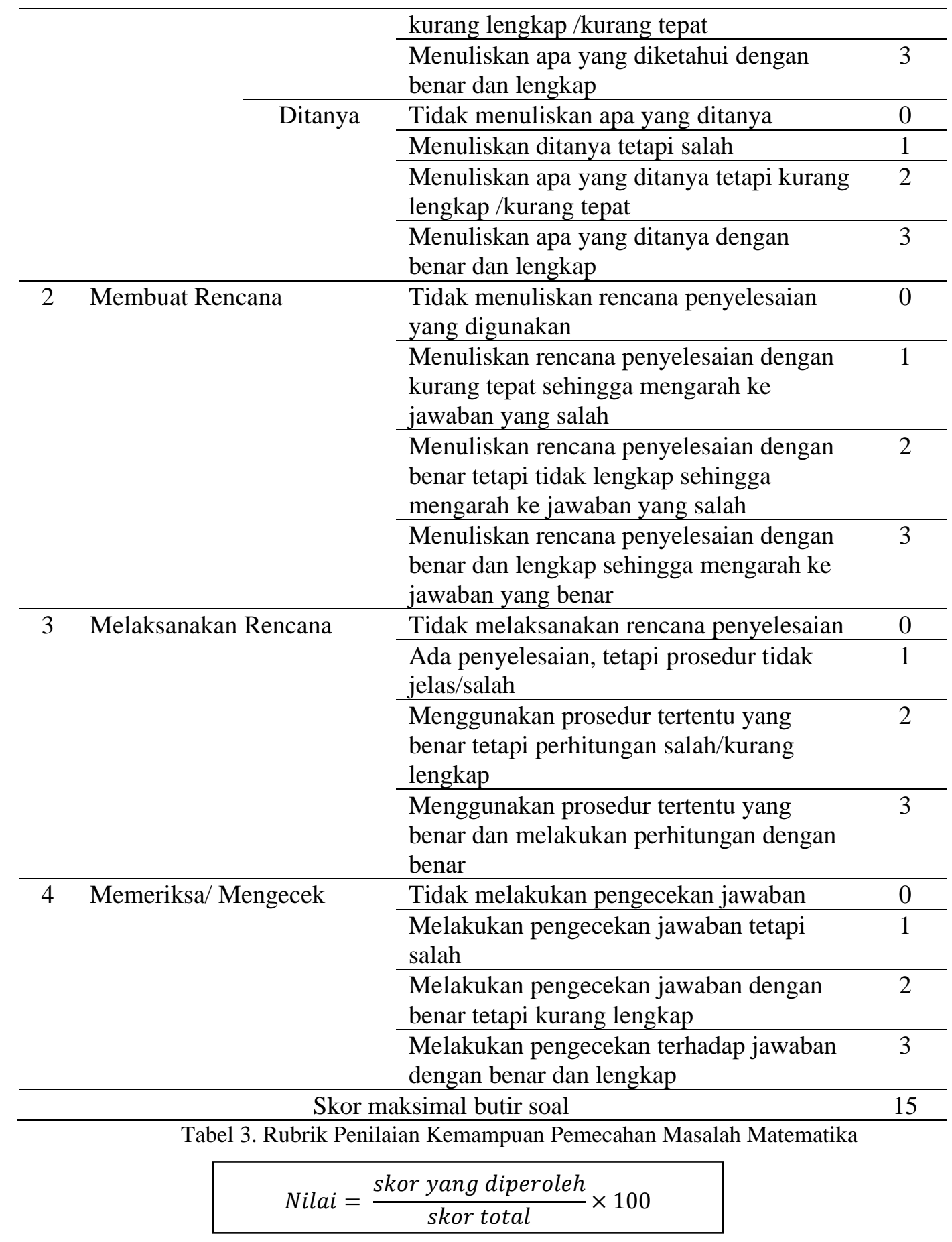

Rata-rata nilai pretest dan posttest kemampuan pemecahan masalah matematika baik kelas eksperimen maupun kelas kontrol dapat dilihat pada gambar berikut. 


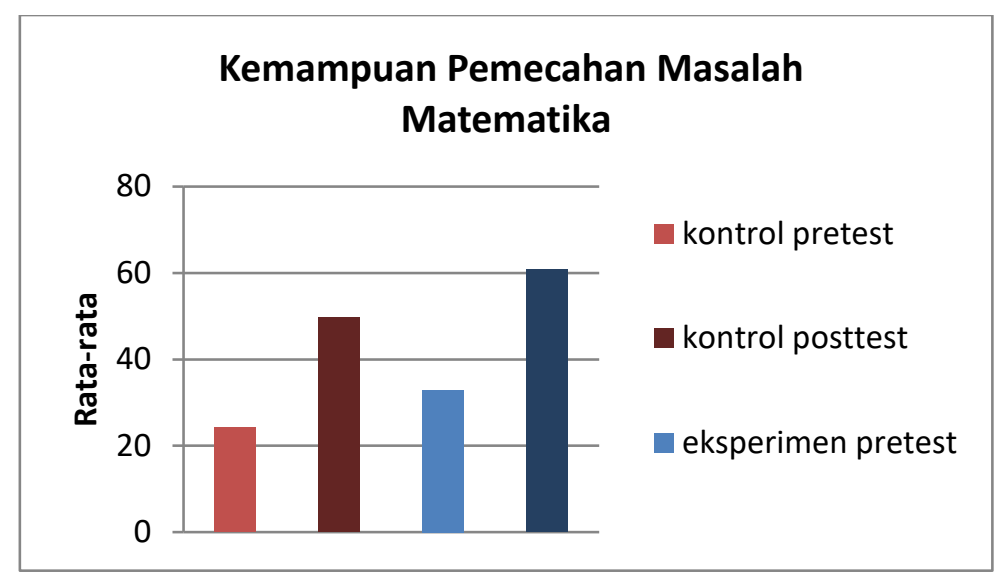

Gambar 1. Rata-rata Nilai Kemampuan Pemecahan Masalah Matematika

Adapun hasil uji prasyarat untuk uji normalitas dan uji homogenitas pada Tabel 4. berikut.

\begin{tabular}{|c|c|c|c|c|}
\hline Variabel Pengujian & Uji Normalitas & Kesimpulan & Uji Homogenitas & Kesimpulan \\
\hline $\begin{array}{l}\text { Data pretest kelas } \\
\text { kontrol }\end{array}$ & $0,16097 \leq 0,227$ & $H_{0}$ diterima & \multirow{2}{*}{$2,39299 \leq 2,761$} & \multirow{2}{*}{$H_{0}$ diterima } \\
\hline $\begin{array}{l}\text { Data pretest kelas } \\
\text { eksperimen }\end{array}$ & $0,1179 \leq 0,242$ & $H_{0}$ diterima & & \\
\hline $\begin{array}{l}\text { Data posttest kelas } \\
\text { kontrol }\end{array}$ & $0,17451 \leq 0,227$ & $H_{0}$ diterima & \multirow{2}{*}{$1,70 \leq 2,761$} & \multirow{2}{*}{$H_{0}$ diterima } \\
\hline $\begin{array}{l}\text { Data posttest kelas } \\
\text { eksperimen }\end{array}$ & $0,222367 \leq 0,242$ & $H_{0}$ diterima & & \\
\hline
\end{tabular}

Dari Tabel 4. diatas pada uji normalitas didapat $H_{0}$ diterima yang berarti data pretest dan posttest dari kelas eksperimen dan kelas kontrol berasal dari data berdistribusi normal. Dan pada uji homogenitas didapat $H_{0}$ diterima yang berarti nilai pretest dan posttest dari kelas eksperimen dan kelas kontrol memiliki variansi yang sama atau homogen.

Pengujian hipotesis dilakukan dengan menggunakan Gain uji-t. Setelah dilakukan perhitungan diperoleh data seperti yang disajikan pada tabel berikut:

\begin{tabular}{|c|c|c|c|}
\hline $\begin{array}{c}\text { Gain Rata-rata Pre- } \\
\text { Post Eksperimen } \\
\left(M_{x}\right)\end{array}$ & $\begin{array}{c}\text { Gain Rata-rata Pre- } \\
\text { Post Kontrol } \\
\left(M_{y}\right) \\
\end{array}$ & $d k t_{\text {hitung }} t_{\text {tabel }}$ & Kesimpulan \\
\hline 29,167 & 19,643 & $2,142 \quad 2,064$ & $H_{0}$ ditolak \\
\hline
\end{tabular}

ditolak. Hal ini berarti bahwa selisih rata-rata kemampuan pemecahan masalah matematika kelas 
eksperimen yang menggunakan model pembelajaran Thinking Aloud Pair Problem Solving (TAPPS) lebih dari selisih rata-rata kemampuan pemecahan masalah matematika kelas kontrol yang menggunakan model pembelajaran langsung. Sehingga dapat disimpulkan bahwa model TAPPS berpengaruh terhadap kemampuan pemecahan masalah matematika peserta didik kelas VIII di SMPIT Darul Muhsin Nahdlatul Wathan pada materi pola bilangan.

Untuk mengetahui seberapa besar pengaruh model pembelajaran TAPPS dalam proses pembelajaran di kelas yang ditinjau dari kemampuan pemecahan masalah matematika peserta didik yaitu menggunakan Effect Size. Hasil perhitungan dapat dapat dilihat pada Tabel 6. berikut.

\begin{tabular}{cccc}
\hline $\begin{array}{c}\text { Mean Kelas } \\
\text { Pretest } \\
\left(\overline{\overline{x_{1}}}\right)\end{array}$ & $\begin{array}{c}\text { Mean Kelas } \\
\text { Posttest } \\
\left(\overline{\overline{x_{2}}}\right)\end{array}$ & $\begin{array}{c}\text { Standar Deviasi } \\
\text { Posttest }\end{array}$ & $\begin{array}{c}\text { Effect Size } \\
(d)\end{array}$ \\
\hline 32,917 & 62,0833 & 15,29 & 1,907 \\
\hline Tabel 6. Hasil Perhitungan Effect Size Kelas Eksperimen
\end{tabular}

Berdasarkan Tabel 6. diatas dapat dilihat bahwa hasil perhitungan Effect Size sebesar 1,907. Berdasarkan kriteria pada Tabel 2. dapat disimpulkan bahwa model pembelajaran Thinking Aloud Pair Problem Solving (TAPPS) mempunyai pengaruh yang tinggi terhadap kemampuan pemecahan masalah matematika kelas VIII di SMP-IT Darul Muhsin Nahdlatul Wathan semester ganjil tahun ajaran 2020/2021

Berdasarkan hasil pengamatan pada saat proses pembelajaran sebanyak empat kali pertemuan di masing-masing kelas, hasil penelitian menunjukkan bahwa peserta didik lebih suliy mengutarakan pikirannya dibandingkan mendengarkan dengan dengan seksama penjelasan dari temannya. Hal ini dikarenakan pembelajaran yang sering diterima oleh peserta didik yaitu pembelajaran langsung, dimana guru secara dominan sebagai pemberi informasi, sehingga peserta didik lebih sering mendengarkan dibandingkan mengutarakan pikirannya.

Hasil penelitian ini juga mengungkapkan kelebihan dan kekurangan dari model TAPPS yang telah diterapkan. Berdasarkan hasil pembelajaran di kelas eksperimen, dan dapat dikatakan bahwa model ini sesuai dengan pernyataan (Junita, 2015) diantaranya yaitu dapat mengembangkan kemampuan peserta didik dalam memecahkan masalah, mengurangi pemikiran impulsive (tanpa perencanaan) dalam memecahkan masalah, dapat meningkatkan keahlian mendengarkan yang aktif, meningkatkan keahlian berkomunikasi, membangun rasa percaya diri dalam memecahkan masalah, dan pola berpikir peserta didik lebih terstruktur. Sedangkan kekurangan model TAPPS yang diketahui berdasarkan hasil pembelajaran saat penelitian sesuai dengan pernyataan (Purwaningrum, 2016) diantaranya yaitu model TAPPS memerlukan banyak waktu, peserta didik sulit menyampaikan gagasan yang ada dipikirannya, memungkinkan adanya kesalahpahaman mengenai penyelesaian masalah dari keterangan yang disampaikan problem solver dan yang dipahami oleh listener, dan 
listener terkadang mengalami kesulitan ketika menuntun atau memberi oetunjuk sekaligus mengoreksi problem solver ketika memecahkan suatu masalah.

Dengan diterapkannya model pembelajaran TAPPS, peserta didik dibagi dalam bentuk kelompok-kelompok dan berdiskusi sehingga dapat mengurangi pembelajaran satu arah dari guru ke peserta didik. Model ini juga membantu peserta didik dalam aktivitas mendengarkan, memecahkan masalah, dan saling bekerjasama dalam memecahkan masalah saat diskusi kelompok. Hal tersebut sejalan dengan pendapat (Setiawati et al., 2015) yang menyatakan bahwa keunggulan model TAPPS, banyak melibatkan peserta didik dalam proses pembelajarannya. Setiap peserta didik pasti akan mendapat giliran sebagai pemecah masalah dimana peserta didik dapat mengungkapkan ide/gagasannya pada temannya yang sebagai pendengar dalam memecahkan permasalahan matematikayang diberikan oleh guru. Selain itu setiap anggota kelompok juga dapat saling belajar mengenai teknik pemecahan masalah satu sama lain, sehingga mereka dapat memahami proses berpikir masing-masing.

Berdasarkan hasil posttest peserta didik, terlihat bahwa sebesar 34,61\% dari peserta didik yang mengikuti posttest nilainya melebihi KKM yaitu 75. Jika diperhatikan, nilai rata-rata hasil kemampuan pemecahan masalah matematika kelas eksperimen dan kelas kontrol masih rendah. Pada saat menggunakan model pembelajaran TAPPS ini tidak sepenuhnya sesuai dengan yang diharapkan, terjadi beberapa kendala yang juga menjadi faktor penyebab kurang maksimalnya kemampuan pemecahan masalah.

Kondisi pembelajaran yang menggunakan model pembelajaran TAPPS ini tidak sepenuhnya sesuai dengan apa yang diharapkan, terjadi beberapa kendala yang juga menjadi faktor penyebab kurang maksimalnya kemampuan pemecahan masalah matematika di kelas eksperimen dan kelas kontrol. Kendala yang dihadapi di kelas eksperimen yaitu ketika membentuk kelompok, tidak dapat diajak berdiskusi, peserta didik tidak mudah untuk menyampaikan apa yang ada dipikirannya kepada pasangannya.

Peningkatan kemampuan pemecahan masalah matematika dimana kelas eksperimen kemampuan pemecahan masalahnya lebih dari kemampuan pemecahan masalah kelas kontrol, dengan aktivitas mengajar guru yang sama-sama berkategori baik serta aktivitas peserta didik yang samasama berkategori aktif di kelas eksperimen dan kelas kontrol, maka dapat diindikasikan bahwa penggunaan model pembelajaran TAPPS memberikan pengaruh terhadap kemampuan pemecahan masalah matematika kelas VIII di SMP-IT Darul Muhsin Nahdlatul Wathan pada materi pola bilangan. Penelitian ini selaras dengan penelitian yang dilakukan oleh (Abduh \& Sutarto, 2014) menyimpulkan bahwa ada pengaruh model TAPPS berbantuan Facebook Learning dan Cabri terhadap kemampuan pemecahan masalah matematika peserta didik, yaitu dilihat dari nilai rata-rata kemampuan pemecahan masalah matematika peserta didik kelas eksperimen lebiha besar dari kelas control. Selain itu, menurut (Sugiyono, 2013) bahwa dalam penelitian, pengaruh treatment (perlakuan) dianalisis dengan uji beda menggunakan Gain Uji-t. jika terdapat perbedaan yang signifikan antara kelompok eksperimen dan kelompok kontrol, maka perlakuan yang diberikan berpengaruh secara signifikan.

Penelitian ini berpengaruh terhadap kemampuan pemecahan masalah, selanjutnya dilakukan uji effect size untuk mengukur seberapa besar kontribusi atau pengaruuh penggunaan model 
pembelajaran TAPPS terhadap kemampuan pemecahan masalah peserta didik. Dalam menggunakan uji effect size ini, maka akan diketahui seberapa besar kontribusi model pembelajaran TAPPS melalui kriteria-kriteria yang telah ditentukan yaitu tinggi, sedang, dan rendah. Hasil perhitungan effect size yang diperoleh dalam penelitian ini adal $d=1,907$, yang dilihat dari kriteria pada Tabel 2. berada pada kriteria tinggi yaitu nilai effect size atau $d>0,8$. Maka dari perhitungan ini dapat dikatakan bahwa setelah diterapkan model pembelajaran TAPPS mempunyai pengaruh yang tinggi terhadap kemampuan pemecahan masalah matematika pada materi pola bilangan di kelas VIII di SMP-IT Darul Muhsin Nahdlatul Wathan tahun ajaran 2020/2021.

\section{KESIMPULAN}

Berdasarkan data hasil penelitian dan pembahasan yang telah dipaparkan sebelumnya, dapat disimpulkan bahwa:

a. Pembelajaran dengan model pembelajaran Thinking Aloud Pair Problem Solving (TAPPS) berpengaruh terhadap kemampuan pemecahan masalah matematika pada materi pola bilangan peserta didik kelas VIII di SMP-IT Darul Muhsin Nahdlatul Wathan tahun ajaran 2020/2021.

b. Besar pengaruh penerapan model pembelajaran Thinking Aloud Pair Problem Solving (TAPPS) terhadap kemampuan pemecahan masalah matematika pada materi pola bilangan peserta didik kelas VIII di SMP-IT Darul Muhsin Nahdlatul Wathan tahun ajaran 2020/2021 dengan menggunakan rumus Effect Size (d) memiliki kategori tinggi.

\section{DAFTAR PUSTAKA}

Abduh, K. \& Sutarto. (2014). Kefektifan Model Pembelajaran TAPPS Berbantuan Facebook Learning Dan Cabri Pada Pencapaian Kemampuan Pemecahan Masalah. UNNES Jurnal of Mathematics Education, 3(1), 57-62. https://doi.org/10.15294/ujme.v3i1.3437

Arikunto, S. (2013). Prosedur Penelitian Suatu Pendekatan Praktik. Jakarta: Rineka Cipta.

Junita, B.A. (2015). Implementasi Think Aloud Pair Problem Solving (TAPPS) Berbantuan Media Kartu Bergambar Terhadap Kemampuan Pemecahan Masalah Dan Hasil Belajar Kognitif Siswa. Jurnal Ilmiah Pendidikan Kimia "Hydrogen", 5(2), 274-282. https://ejournal.undikma.ac.id/index.php/hydrogen/issue/view/86

Khabibah, S. \& Sari, M.N. (2017). Penerapan Pembelajaran Thinking Aloud Pair Problem Solving (TAPPS) Pada Materi Bangun Ruang Sisi Datar Kelas VIII SMP Negeri 1 Turi Lamongan. Jurnal Ilmiah Pendidikan Matematika $\quad$ (JIPM), $\quad 3(6), \quad$ 98-106. https://doi.org/10.26740/mathedunesa.v6n3.p\%25p 
Purwaningrum, J.P. (2016). Disposisi Matematis Siswa SD Melalui Model Pembelajaran Thingking Aloud Pair Problem Solving. Suska Jurnal of Mathematica Education, 2(2), 125-130. http://dx.doi.org/10.24014/sjme.v2i2.2200.

Setiawati, N.L.P., Dantes, N., \& Candiasa, I.M. (2015). Pengaruh Model Pembelajaran Kooperatif Thinking Aloud Pair Proble Solving (TAPPS) Berbantuan LKS Terhadap Sikap Sosial Dan Hasil Belajar Matematika Siswa Kelas VI SLB Negeri Gianyar. Jurnal Program Pascasarjana Universitas Pendidikan Ganesha Program Studi Penelitian dan Evaluasi Pendidikan, 5(1), 1-10. https://doi.org/10.23887/jpepi.v5i1.1544

Sugiyono. (2013). Metode Penelitian Kombinasi (Mixed Methods). Bandung: Alfabeta.

Suherman, E. (2003). Strategi Pembelajaran Matematika Kontemporer. Bandung: Universitas Pendidikan Indonesia.

Sundayana, Rostina. (2016). Statistika Penelitian Pendidikan. Bandung: Alfabeta.

Trianto. (2007). Model-Model Pembelajaran Inovatif Berorientasi Konstruktivistik. Surabaya: Prestasi Pustaka.

Turmuzi, M. (2017). Strategi Pembelajaran Matematika. Mataram: FKIP Universitas Mataram.

Turmuzi, M., Sripatmi., Azmi, S., \& Hikmah, N. (2018). Penerapan Model PembelajaranCreative Problem Solving (CPS) Untuk Meningkatkan Kemampuan Pemecahan Masalah Mahasiswa Pendidikan Matematika. Jurnal Pijar MIPA, XIII(1), 45-50. http://dx.doi.org/10.29303/jpm.v13i1.470

Warsono \& Hariyanto. (2017). Pembelajaran Aktif Teori dan Asesmen. Bandung: PT Remaja Rosdakarya.

Wijayanti \& Taat. (2016). Efektivitas Model CTL Dan Model PBL Terhadap Hasil Belajar IPS. Harmoni Sosial Jurnal Pendidikan IPS, 3(2), 116. https://doi.org/10.21831/hsjpi.v3i2.7908

Wulandari, A. N., Sukestiyarno, Y. L., \& Sugiman. (2013). Pengembangan Karakter dan Pemecahan Masalah Peserta Didik Melalui Pembelajaran Matematika dengan Model TAPPS Berbantuan Kartu Permasalahan Kelas VII Pada Materi Segiempat. UNNES Journal of Mathematics Education, 2(3), 40-46. https://doi.org/10.15294/ujme.v2i3.3364

How to cite : Nusywari, W., Prayitno, S., Junaidi., \& Hikmah, N., 2022. Pengaruh Penerapan Model Pembelajaran Thinking Aloud Pair Problem Solving (TAPPS) terhadap Kemampuan Pemecahan Masalah Matematika. Jurnal Riset Pendidikan Matematika Jakarta. 4(1). 23-33. https://doi.org/10.21009/jrpmj.v4i1.23023

To link to this article: $\underline{\text { https://doi.org/10.21009/jrpmj.v4i1.23023 }}$ 